\title{
Vulvar Deep "Aggressive" Angiomyxoma
}

National Cancer Institute

\section{Source}

National Cancer Institute. Vulvar Deep "Aggressive" Angiomyxoma. NCI Thesaurus. Code C40322.

A locally infiltrating, non-metastasizing vulvar angiomyxoma. It may recur following resection. 